This is a self-archived version of an original article. This version may differ from the original in pagination and typographic details.

Author(s): Lehesvuori, Sami; Ramnarain, Umesh; Viiri, Jouni

Title: Challenging Transmission Modes of Teaching in Science Classrooms : Enhancing Learner-Centredness through Dialogicity

Year: 2018

Version: Accepted version (Final draft)

Copyright: ㅇ Springer Science+Business Media Dordrecht 2017

Rights: In Copyright

Rights url: http://rightsstatements.org/page//nC/1.0/?language=en

Please cite the original version:

Lehesvuori, S., Ramnarain, U., \& Viiri, J. (2018). Challenging Transmission Modes of Teaching in Science Classrooms : Enhancing Learner-Centredness through Dialogicity. Research in Science Education, 48(5), 1049-1069. https://doi.org/10.1007/s11165-016-9598-7 


\title{
Challenging transmission modes of teaching in science classrooms: Enhancing learner-centredness through dialogicity
}

\section{Author information:}

Sami Lehesvuori*

Ph.D.

e-mail: sami.lehesvuori@jyu.fi

Affiliation: University of Jyvaskyla, The Department of Teacher Education,

P.O. Box 35, 40014 JYVASKYLAN YLIOPISTO, Finland

*Corresponding author: Tel. 00358445722080

prof. Umesh Ramnarain

Ph.D.

e-mail: uramnarain@uj.ac.za

Affiliation: University of Johannesburg, The Department of Science and Technology Education

P.O. Box 524, Auckland Park 2006, South Africa

prof. Jouni Viiri

Ph.D.

e-mail: jouni.viiri@jyu.fi

Affiliation: University of Jyvaskyla, The Department of Teacher Education,

P.O. Box 35, 40014 JYVASKYLAN YLIOPISTO, Finland

\begin{abstract}
There is an ongoing reform towards more inquiry-based teaching in school curriculum policy in South Africa. Reform towards more inquiry-based approaches is already integrated in preservice teacher education programmes. As inquiry-based approaches have been gaining momentum worldwide, there is an increasing concern that dialogic interaction in classroom communication is being neglected. This is especially within teacher-orchestrated classroom interactions that should foster greater learner-centredness, and thus authentic scientific inquiry. In learner-centred teaching approaches, student contributions should be explicitly taken into account as part of classroom interactions in science. Learner-centred approaches provide the rationale for improved interaction, especially when student contributions should be considered within teacher-orchestrated communications. The aim of this study is to bring forth indicators that are connected to different forms of interactions and complement the dialogic-authoritative categorization through in-depth analysis of two lesson transcript examples. Even though over-authoritative and even transmission modes of communication seemed to prevail in South African classrooms, it is through finding building blocks for dialogicity this status can be challenged towards more learner-centred interaction. The explicitness of dialogicity, and fundamentally contrasting differences between examples of dialogic and authoritative approaches, is presented through the indepth analysis of classroom interactions of two case episodes. Implications for teaching and teacher education are discussed.
\end{abstract}

Key words: Classroom interactions in science; dialogic teaching; dialogic indicators; communicative approaches; teacher education 


\section{Introduction}

A significant reform in South African school science curricula has been a shift towards inquiry-based teaching approach (Department of Basic Education, 2011). In science education, inquiry commonly refers to three main ideas covering: learning to do inquiry; learning about inquiry (conceptual understanding about inquiry); and learning through inquiry (Bybee, 2000). In this study we focus on the pedagogical approaches, and in particular in the types of classroom interactions that should be manifested within inquirybased learning. The sociocultural perspective, grounding the importance of social and more dialogic interactions, has become increasingly popular in educational research (e.g., Alexander, 2006; Littleton \& Howe, 2009; Mortimer \& Scott, 2003), thus rationalizing the focus on classroom interactions also in science classrooms.

The traditional science curriculum in South Africa placed much emphasis on the transmission of scientific knowledge, was teacher-centred, and portrayed the learner in a passive role (Ramnarain \& Kibirige, 2010). In such a teacher-centred science classroom, communication flows from the teacher to the learner and teacher talk dominates the lesson. Traditional transmission modes of teaching have been criticised for limiting learners' opportunities to share their everyday conceptions (e.g., Lemke, 1990), and yet they still dominate the science classroom (Lehesvuori, Viiri, Rasku-Puttonen, Moate, \& Helaakoski, 2013; Mercer, Dawes, \& Staarman, 2009; Wells \& Arauz, 2006). It was anticipated that the introduction of inquirybased learning would redefine this traditional science teacher-learner relationship, and hence shift the communication pattern in the classroom towards more learner-centred. Within inquiry-based learning, understanding is enriched by engagement of ideas in concert with other people (Anderson, 2007), which can at first be modelled, and then facilitated, through teacher-orchestrated classroom interactions. This means, that despite lessons being teacherorchestrated, the teacher should facilitate interactivity, reciprocity, cumulativity and collectivity. This idea is underpinned in Alexander's (2006) holistic definition for dialogic teaching. In this study, we investigate dialogicity in differentiating learner-centred from teacher-centred approaches. 
It has been discussed that the knowledge which the learner gains is constructed within cognitive structures, and depends on experiences in the social learning environment (Grabinger \& Dunlap, 1995). In this setting, according to Fosnot (1996):

"the traditional hierarchy of the teacher as the autocratic knower and learner as the unknowing, controlled subject studying to learn what the teacher knows begins to dissipate as teachers assume more of a facilitator's role and learners take on more ownership of the ideas" (p.4)

A combination of instructional and pedagogical approach inquiry can truly provide a stimulus for dialogic classroom interactions. In preparing teachers to implement inquiry-based learning in their classrooms, science teacher education programmes now place a strong emphasis worldwide on this pedagogy. It is against this background of the curriculum reform, and the anticipated redefining of teacher-learner interactions, that this study explored interactions evident in pre-service teacher (abbreviated as PST) field lessons.

Both dialogicity and authoritativeness are an integral part of science teaching. Whereas different ideas (e.g., scientific and everyday ideas) are considered mutually within dialogic interaction (Bakhtin, 1986), the view of science is prevalent in authoritative one. Similarly, it has been discussed that inquiry should be supported by both authoritative and dialogic approaches (Lehesvuori, Ratinen, Kulhomäki, Lappi, \& Viiri, 2011). Yet, when it comes to the rationale for challenging the teacher-centred and monotonic communication approaches often related to teaching and learning of science (Lyons, 2006), it should be emphasised that many scientific ideas and theories have been fundamentally developed over time and shaped by the results of dialogues and scientific argumentation (Driver, Asoko, Leach, Mortimer \& Scott, 1994; Osborne, 2014). Furthermore, despite the arguable need for teacher control and support when navigating learners through school science, the overuse of teacher-centred approaches could result in learners finally losing their interest in science (Lyons, 2006). Consequently, there is a call for learner-centred approaches that initiate student participation through talking and 'making' science (Peters, 2010). There is recent evidence that learnercentred approaches, within a teacher-orchestrated classroom interactions, led to improved motivation to learn science (Kiemer, Gröshner, Pehmer, \& Seidel, 2015). Learner-centred approaches are often linked to instructional models such as experimental work and active learning, which do not always result in learning, since also the quality and nature of communications (and dialogicity) should be considered (Andrews, Leonard, Colgrove, \& 
Kalinowski, 2011). Within this study, learner-centredness is assimilated to dialogic interactions where learner contributions are explicitly taken into account in science lessons.

Inquiry guidelines integrated into the science curriculum can have an effect on classroom interaction (Wells \& Arauz, 2006). In their study Wells and Arauz found that there was moderate change towards more dialogic interactions in classroom communications after inquiry teaching had been integrated into curricula in Toronto, Canada. More specifically, it was found in the teacher-learner interactions that there was a decrease in the proportion of sequences initiated by a teacher question, and inversely, an increase in learner initiation of sequences. At the same time, however, inquiry curriculum guidelines have been criticized for neglecting the social aspect of teaching and learning (Oliveira, 2009, 2010). Indeed, scientific inquiry should involve an interplay between theoretical models and empirical investigations, linked by critical scientific argumentation through social interaction (Osborne, 2014). In Finland, for example, inquiry is often misleadingly related to brief 'cookbook' tasks within which empty time slots are merely filled, rather than authentically engaging learners in the making of science (Saari \& Sormunen, 2007). Based on research on classroom interaction in science (e.g., Chin, 2007; Lemke, 1990; Mercer, Dawes, \& Staarman, 2009; Mortimer \& Scott, 2003), the learning of science should involve constructing knowledge through inquiry and dialogue, rather than simply recreating science and assimilating knowledge.

Having said this, it can be noted that there is still limited work that explicitly connects different forms of communication with different phases of scientific inquiry (Lehesvuori et al., 2011) and how they manifest, especially during teacher-orchestrated interactions. Teacher-orchestrated classroom interactions are essential, since it is through teacher examples that learners can model appropriate ways to engage in constructive interactions during whole-class discussions, and also between peers (Webb, 2009). Based on this background, it was worthwhile to investigate whether the inquiry-based approaches to teaching, already integrated into South African school curriculum policy and teacher education, are really manifesting in scientific inquiry. Since the initial investigations of the data revealed only hints of dialogicity, the objective now was to identify the very root level actions needed to foster learner-centredness and dialogicity in scientific inquiry.

The aim of the study was to explore dialogic approach in the teaching of reform-prepared South African PSTs. The different forms of interaction were initially identified using the 
concept of 'communicative approach' (Mortimer \& Scott, 2003), which has proved useful in the analysis of classroom interaction in a varying range of cultures such as Brazil, United Kingdom (Mortimer \& Scott, 2003; Scott, Mortimer, \& Aguiar, 2006) and Finland (Lehesvuori et al., 2013). In this study this theoretical framework was adapted to analyse classroom interactions orchestrated by PSTs in South Africa. Yet, as realized, dialogicity was extremely infrequent. Only one case was found in the data-set. This led to exploring in-depth the nature of this dialogic example and individual indicators which finally led to sufficient dialogicity. Compared to previous studies conducted in the field of classroom interaction in science, this study contrasts extreme examples of indicators for authoritative and dialogic interactions in a way that brings further explicitness to the scholarly, and often holistic, definitions of dialogicity. By drawing on cases, concrete ways to challenge the prevailing authoritativeness and to reach dialogicity is highlighted and discussed. There is sophisticated underpinnings of principles, repertoires and indicators for dialogicity (Alexander, 2006, p.3743). However, we need more explicit examples emerging from the data. This is an important aspect when discussing implications for teaching and science teacher education.

\section{Classroom Interaction in Science}

We begin our literature review from more holistic descriptions for classroom interactions and proceed then towards the focus of this paper being the more micro-scale indicators for specific communicative approaches.

The communicative approach. This framework differentiates between typical transmission mode teaching and classroom interaction in which learners are given the freedom to, for example, describe, compare, classify and argue when taking part in discussions. Mortimer and Scott's (2003) framework for describing classroom discourse consists of four categories generated from the combination of two dimensions: interactive/non-interactive and dialogic/authoritative. Interactive talk allows learners to participate, whereas non-interactive talk takes the form of a lecture type. Dialogic approaches takes account of diverging ideas, while the authoritative approaches focus on a specific point of view, usually the scientific view as delivered by the teacher. The four categories of classroom discourse are described below: 
- In the question-answer routine of the authoritative and interactive approach, learners' responses are often evaluated and the teacher neglects diverging ideas. The authoritative approach focuses on the scientific point of view.

- In contrast, the dialogic and interactive approach explores and exploits learners' ideas (e.g., everyday views), and has no evaluative aspect. Thus, the dialogic approach, in Mortimer and Scott's categorisation, is considered when the teacher is not trying to achieve a specific point of view. Rather, the teacher tries to elicit the learners' points of view and works with these contrasting views.

- In the authoritative and non-interactive approach, the teacher presents scientific content by lecturing and takes no account of contrasting points of view.

- In the dialogic approach and non-interactive, the teacher works with contrasting points of view, such as learners' everyday views, and moves on to present the scientific view. Thus, even though the teacher is lecturing, diverging ideas are discussed. The teacher talk is therefore dialogic by nature.

It should be noted that the communicative approach does not consist of a single sentence of a teacher-learner exchange. A communicative approach consists of a series of teacher-learner exchanges that should align with the specific teaching purpose. Thus, the analysis of communicative approaches involves careful consideration of the prevailing types of teacherled talk or chains of teacher-learner exchanges. This is something that teachers should pay attention to when planning and reflecting on the dominant communicative approach taking place within an entity of an episode. However, as sequential patterns constitute episodes within a certain communicative approach, teachers should still consider single turns in order to avoid repeating evaluation of responses, especially if planning to apply dialogic approaches. The turn could be defined for example as teacher initiation, learner response or teacher feedback. A single turn could consist of a single word, sentence or sequential sentences (described in more detail in the next section). It should be emphasised that although authoritative approaches can be an important part of learner-centred teaching, the overuse of this approach can lead to teacher-centred and transmission modes of teaching.

Teacher initiation and feedback as indicators for dialogicity. Lemke has conducted some of the most significant groundwork in recent decades on discourse in science (Lemke, 1990). Lemke and many other scholars (Driver, Asoko, Leach, Mortimer \& Scott, 1994; Mortimer $\&$ Scott, 2003; Bleicher, Tobin, \& McRobbin, 2003) note that the essence of science learning 
is learning how to 'talk science'. According to Lemke, a typical form of science teaching is often considered to be a dialogue initiated by the teacher, followed by a learner response, which is followed again by feedback from the teacher. This three-turn pattern of talk also known as the IRF pattern of discourse, where 'I' stands for the 'Initiation of the teacher' (such as a question), ' $R$ ' for the 'Response of the student' and ' $F$ ' for the 'Feedback (or follow-up) of the teacher' (Sinclair \& Coulthard, 1975).

Initiations are usually assimilated to teacher questioning especially in whole-class discussions. Questions are often defined as either closed or open. The type most associated with initiating and indicating dialogic interaction is the open question (Chin, 2007). Closed questions rarely lead to dialogic interaction; instead they aim for pre-defined answers and offer no flexibility with respect to the learner's response. Open questions, on the other hand, elicit something from the learner, such as explanations or predictions. Open-ended questioning is also closely related to "real" (Furtak \& Shavelson, 2009) or "authentic" questioning (Nystrand, Gamoran, Kachur, \& Prendergast, 1997) where the answer is not necessarily known or expected by the teacher. Open questions aim to stimulate, explore and prompt learners' thinking beyond merely memorising facts. Furthermore, open questioning has been associated with better learning outcomes and positive attitudes towards learning science (She \& Fisher, 2002). Open questioning may be considered an indicator of dialogicity (Alexander, 2006, p. 41)

Accordingly, another obvious indicator for possible dialogicity is teacher feedback. If teacher feedback is however evaluative, the pattern can be written as IRE, where ' $E$ ' stands for 'Evaluation' (Mehan, 1979) and the interaction is indicating authoritative approach. The nature of teacher feedback $(\mathrm{F})$ is considered essential for activating learner thinking and reasoning - particularly when feedback extends beyond evaluation (Cullen, 2002; Nassaji \& Wells, 2000). The challenge of categorising a single feedback event when it becomes evaluative, neutral or supporting, without considering the temporal surroundings, linguistic (e.g., personal pronouns) and paralinguistic features (such as wait time and intonation), has been previously discussed (Chin, 2004; Murakami \& Skidmore, 2010; Oliveira, 2011; Lehesvuori, Viiri, \& Rasku-Puttonen, 2011; Lehesvuori et al., 2013).

In relation to the above, a more recent, yet well known, derivation and extension of the triadic talk pattern is the IRFRF - chain (e.g., Mortimer \& Scott, 2003) in which learner responses 
are followed by the teacher directing the turn back to the learners without evaluation. For instance, the teacher might elicit learners' points of view without evaluating their responses, but instead prompting the learners for further thinking (Scott, Mortimer, \& Aguiar, 2006). The way different formations of chains are linked to communicative approaches is addressed in more detail in Lehesvuori et al. (2013), yet Figure 1 illustrates this connection briefly. The implication of the chain-formed patterns is their potentiality to engage learners in more interactive and supportive teacher-learner interactions (Rojas-Drummond, Mercer \& Dabrowski, 2001), thus the chain patterns often hold promise in promoting a dialogic approach.

\begin{tabular}{c|c|c|}
\multicolumn{1}{c}{} & \multicolumn{1}{c}{ Interactive } & Non-interactive \\
\cline { 2 - 3 } Authoritative & question \& answer & \\
Focus on science view & routine & teacher instruction \\
& IRF & lecturing \\
IRE & review \\
Alternative views are & probing & \\
considered & supporting & elaborating \\
\end{tabular}

Figure 1: Communicative approaches, main characteristics and their relation to common patterns of talk (adapted from Mortimer \& Scott, 2003)

Studies over the decades reveal the same result - that far more than $50 \%$ of teaching follows the triadic IRF pattern (E.g., Edwards \& Mercer, 1987; Mercer, Dawes, \& Staarman, 2009). It would be beneficial to examine any variations of this pattern that might promote dialogic interaction and, more particularly, how dialogic indicators and learner-centredness are explicitly present in single turns and sentences within teacher-orchestrated interactions. This is one of the key interests of this study that delves into case examples of two different episodes, within in addition to "what" we focus on "how" teacher manifests indicators finally constituting a specific communicative approach. By doing this, we shall characterize further the repertoires teachers can enroll in order to challenge the prevailingly authoritative classroom interactions in science. 


\section{Method}

\section{Study Objectives}

The initial analysis delved into the overall communicative nature of PSTs' lessons in South Africa and the aim was to explore whether dialogicity featured in PSTs' lessons during their field practice. The initial analysis of the data-set revealed that dialogic approach was extremely infrequent. This led the study towards an exploration of an exemplary dialogic episode complemented with analysis of one authoritative episode as a comparative case. Subsequently, the objective of the study became:

- to explore and to highlight the differences between dialogic/interactive and authoritative/interactive approaches through recognition of explicit indicators and concrete examples.

In this way we hoped to demonstrate the extremes of these interactive approaches according to the communicative approach framework. The results of this study further explicate previous definitions and examples provided in literature, in particular, through in-depth analysis of classroom interactions.

\section{The Context}

Selection of the two cases. The selection procedure involved the video analysis of the communicative approaches of nine student-teachers, which was complemented with the video analysis of three in-service teachers. Only one of the PSTs (pseudonym John) displayed a dialogic approach briefly in one episode in his teaching sessions. In order to highlight the difference between the dialogic and authoritative approach, another PST's (pseudonym George) episode was selected as a counter example with a leaning towards a very teachercentred and transmission mode of teaching, realised via a highly authoritative communicative approach. Briefly, the PSTs and their example episodes were, therefore, purposefully selected as contrasting cases of dialogic and authoritative approaches and the further characterization of indicators. The two PSTs, George and John, were in their final year of their Bachelor of Education qualification. They both conducted their field training in township schools. Note 
that in South Africa, the term 'township' usually refers to underdeveloped urban areas that, from the late 19th century until the end of apartheid, were set aside for 'non-whites'. Townships were usually on the periphery of towns and cities, the communities had low socioeconomic status, and residents commuted to predominantly 'white' areas to work. Despite attempts by the post-apartheid government to redress historical imbalances, these township schools remain poorly resourced and have scant facilities for practical work in science. Students' parents are generally poorly educated and have low-paying jobs. Fees at these schools are low and in some cases schools may be classified as no-fee schools.

\section{Data Collection}

PSTs video recorded one lesson during their field training period in a real classroom. In our previous studies (Lehesvuori et al., 2013) we found that one video camera following a teacher can suffice in providing sufficient data for the analysis of whole-class teaching sessions. The reasons for focusing on whole-class teaching sessions are: Firstly, initial analysis of this study revealed that there wasn't really authentic inquiry or even learner group work; Secondly, it has been noted that it is through teacher-orchestrated talk during whole-class teaching sessions that the monotonic communicative spectrum in classrooms can be (and should be) enriched at first hand (McMahon, 2012; Myhill, 2006). The lessons conducted by George and John that formed the focus of this research were taught to grade 10 physical sciences learners. George's lesson was on the periodic table, and John taught the class about wave motion.

\section{Data Analysis}

The initial video-analysis was guided by the communicative approach framework (Mortimer $\&$ Scott, 2003) adopted and adapted for analysis methods and used widely in earlier studies (Lehesvuori et al., 2013; McMahon, 2012; Scott, Mortimer, \& Aguiar, 2008). Whereas the initial categorisation of the communicative approaches takes place at episode1 level (mesolevel; see Lehesvuori et al., 2013), the final interpretations relating to the differences between

1 Each episode was defined according to the dominant communicative approach (dialogic, authoritative) and the level of interaction. In more detail, an episode constitutes of specific activity, topic, teaching purpose carried through via specific communicative approach (see Author et al., 2013). The end of an episode is considered by changes in activity, topic and/or communication, which at the same time indicates the beginning of the next episode. 
communicative approaches are conducted through the micro-analysis of turns and sentences, which is the main analytical approach conducted and presented in this study. Whereas some common indicators are presented alongside communicative approaches in table 1, further examples and characterizations will take place in the findings section. The discourse analysis addresses theoretically the patterns of talk introduced earlier and further explicates the fundamental differences between authoritative and dialogic approaches by more data-driven analysis. This way, the further explication of common (theory-driven) dialogic indicators is complemented with charachterisation of interpretative level (data-driven) indicators emerging from the data (cf., Braun \& Clarke, 2006).

The micro-level analysis conducted in this study draws originally on the general principles of sociocultural discourse analysis complemented with conversation analysis techniques. Whereas a sociocultural approach to analysis of discourse is less focused on language itself and more on the functions language serves for joint activities analysis (Mercer, 2004), the conversational analysis techniques provide ways to access data-emerging patterns (Hsu, Roth, \& Mazumder, 2009) or single turns such as teacher feedback (Hall, 2007; Macbeth, 2004; Cullen, 2002). In order to open up these data-driven features in enough detail, transcribed episodes are distributed in sub-units of segments consisting of a single turn or few turns (cf. Lefstein \& Snell, 2014).

Table 1: Extended categorisation criteria for communicative approaches and talk patterns complemented with indicators for communicative approaches (Note: Abbreviations for pattern turn in brackets and indicators as underlined)

\begin{tabular}{|l|l|l|}
\hline \multicolumn{1}{|c|}{$\begin{array}{c}\text { Communicative } \\
\text { approach }\end{array}$} & \multicolumn{1}{|c|}{ Transcript example } & $\begin{array}{l}\text { Related pattern(s) and } \\
\text { indicators detected } \\
\text { (with abbreviation) }\end{array}$ \\
\hline $\begin{array}{l}\text { Authoritative and } \\
\text { non-interactive }\end{array}$ & $\begin{array}{l}\text { Teacher: Now, here we see a model of a hydrogen gas } \\
\text { molecule. The hydrogen gas molecule has two hydrogen } \\
\text { atoms with a covalent bond formed by a pair of } \\
\text { electrons... }\end{array}$ & $\begin{array}{l}\text { Lecturing (L) } \\
\text { (we referring to } \\
\text { scientists as in Oliveira, } \\
\text { 2011) }\end{array}$ \\
\hline $\begin{array}{l}\text { Authoritative and } \\
\text { non-interactive/ } \\
\text { interactive }\end{array}$ & $\begin{array}{l}\text { Teacher: There are two different types of waves. The } \\
\text { other is longitudinal and the other is called a transverse } \\
\text { wave... by the way do you have an example of a } \\
\text { transverse wave? }\end{array}$ & $\begin{array}{l}\text { Lecturing (L) } \\
\text { Embedded question (I) }\end{array}$ \\
\hline
\end{tabular}




\begin{tabular}{|c|c|c|}
\hline & 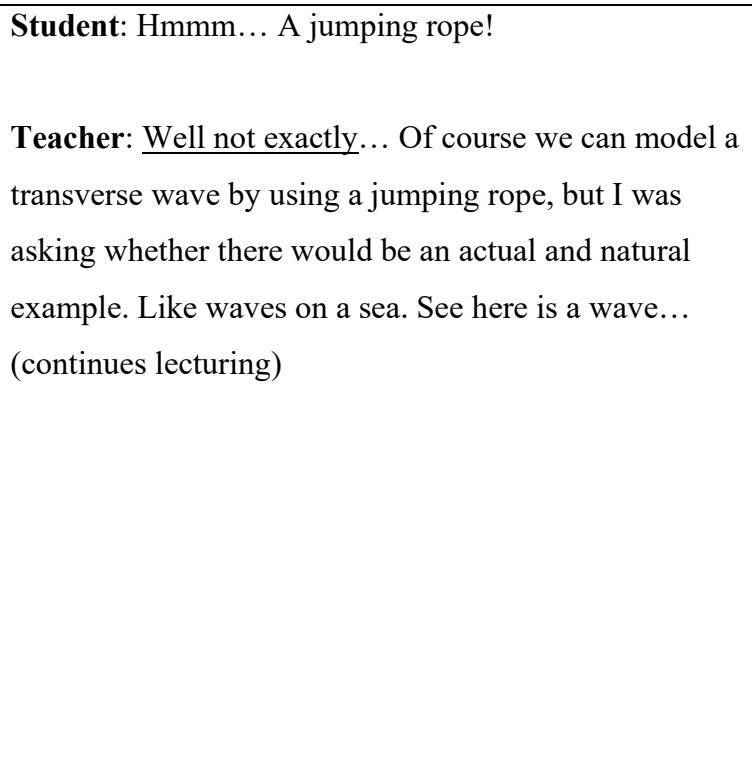 & $\begin{array}{l}\text { Response (R) } \\
\text { Feedback } \\
\text { (/Evaluation=E2) (F) } \\
\text { Lecturing (L) } \\
\text { (Controlling the } \\
\text { direction of discourse } \\
\text { through mini-lecturing) } \\
\rightarrow \text { L-IRF-L*X (X } \\
\text { stands for repetition of } \\
\text { the pattern) }\end{array}$ \\
\hline $\begin{array}{l}\text { Authoritative and } \\
\text { interactive }\end{array}$ & $\begin{array}{l}\text { Teacher: What does the capital letter } E \text { stand for in this } \\
\text { equation? } \\
\text { Student: For power? } \\
\text { Teacher: No! It stands for energy! Well what about } U \text { ? } \\
\text { (Continues with IRE-structure) }\end{array}$ & $\begin{array}{l}\text { Closed initiation }(\mathrm{I}) \\
\text { Response }(\mathrm{R}) \\
\text { Feedback (/Evaluation) } \\
(\mathrm{F}) \\
\rightarrow \mathrm{IRF} * \mathrm{X}\end{array}$ \\
\hline $\begin{array}{l}\text { Dialogic and } \\
\text { interactive }\end{array}$ & $\begin{array}{l}\text { Teacher: Can you explain what causes the container to } \\
\text { explode under pressure? (Wait time) } \\
\text { Student 1: Isn't it like when you put a plastic bottle } \\
\text { that's filled with air into water, or like, under the water, } \\
\text { and it squashes because of the pressure? } \\
\text { Teacher: Do you know why that happens, can you } \\
\text { explain further? } \\
\text { Student 2: Well it's because... I can't remember. } \\
\text { Teacher: That's all right. I think it will become clearer } \\
\text { during the lesson. (Note1: this is a short example of a } \\
\text { chain. The chain is left open without final evaluation at } \\
\text { this point; Note 2: Could include closing down via } \\
\text { evaluation turn in the very end). }\end{array}$ & $\begin{array}{l}\text { Open initiation (I) } \\
\text { (You referring to all } \\
\text { students complemented } \\
\text { with wait time) } \\
\text { Response (R) } \\
\left.\text { Feedback (/Prompt }=\mathrm{P}_{3}\right) \\
\text { (F) } \\
\text { Response (R) } \\
\text { Feedback (F) } \\
\text { (/Supportive/Left open) } \\
\rightarrow \text { IRFRF...(left open) }\end{array}$ \\
\hline Dialogic and non- & Teacher: ... The energy converts to another form. As & Lecturing (L) \\
\hline
\end{tabular}

2 Is congruent with the IRE-pattern (in which E stand for evaluation) originally introduced by Mehan (1979). 3 Is congruent with the IRPRP-pattern (in which P stands for prompt) originally introduced by Scott, Mortimer, \& Aguiar (2006). 


\begin{tabular}{|c|c|c|}
\hline interactive & $\begin{array}{l}\text { you said, for example, to sound, against gravitation and } \\
\text { other forms, which all were good notions. But when we } \\
\text { think in terms of energy 'loss'... Well, some is lost as } \\
\text { sound, but it's mostly through air friction as heat...the } \\
\text { energy changes form to heat when air particles collide } \\
\text { with the ball... (Reviews student responses and shifts } \\
\text { towards more scientific explanations.) }\end{array}$ & $\begin{array}{l}\text { (Note: You referring to } \\
\text { different/student views } \\
\text { are present in teacher } \\
\text { lecturing } \rightarrow \text { Dialogic } \\
\text { approach is taking } \\
\text { place but teacher } \\
\text { implies moving } \\
\text { towards science view } \\
\text { with personal pronoun } \\
\text { we referring to } \\
\text { scientists) }\end{array}$ \\
\hline $\begin{array}{l}\text { Dialogic and } \\
\text { non-interactive/ } \\
\text { interactive }\end{array}$ & Not found/coded & Not found/coded \\
\hline
\end{tabular}

Trustworthiness. Researcher triangulation involving each of the authors was conducted throughout the study process (Miles \& Huberman 1994; Cohen, Manion, \& Morrison, 2007). The initial video analysis was conducted first independently by the first two authors. The interpretations were evaluated and discussed among all of the authors until consensus was established. Also external and independent research colleagues were able to comment on the research and interpretations during the process in international scholarly presentations. The characterization of the segments originates partially from the open discussions held in scholarly presentations. During open discussions, specific parts of the episodes evoked the same emerging themes from different scholarly audiences. The final characterization was discussed and decided collaboratively by the authors. We mostly "stay close to the particulars" within cases (Simons, 2015, p. 183), although the two cases are illustrated in terms of partial comparison.

\section{Findings}

It is noted, when it comes to the scale of the whole lesson, the prevailing form of communication in both teachers' lessons presented here (and the overall data set of the initial analysis) is authoritative. The key point here is, however, that only John can break this prevailing authoritativeness as his lesson includes the only dialogic episode (duration 1 minute) of the overall data consisting of 12 pre- and in-teachers. This episode featured the 
introduction to the lesson on waves. The example from George's lesson was selected since it represents a transmissive approach to teaching, thus a highly opposing form of communication (duration 1 minute) compared to John's case. The variations in turns and their close temporal surroundings affect the communicative nature of these example episodes' interactions. Attention is paid to any indicators manifesting either dialogicity or authoritativeness. All in all, the initial video analysis is supported here through in-depth discursive analysis.

\section{Pre-Service Teacher Examples of Communicative Approaches}

George: Excluding learners from science. This lesson covered covalent bonding between elements using Lewis structures. The episode is characterized with the following segments: Engaging with the day's topic, excluding students, singalong science. The selection of the segments originate from the data and external commenters and were agreed upon among all of the authors. Each segment will be given thorough consideration by applying discourse analysis described earlier. Some essential conversation analysis conventions are included and opened up in transcriptions, yet we have limited their use in terms of reading fluency.

\section{Engaging with the day's topic.}

At the start of the lesson, George referred to a definition of covalent bonding in the textbook. Thereafter, he explained how covalent bonding takes place between hydrogen and oxygen in the water molecule using Lewis structures. Covalent bonding involving hydrogen, chlorine and iodine is discussed when George poses a question:

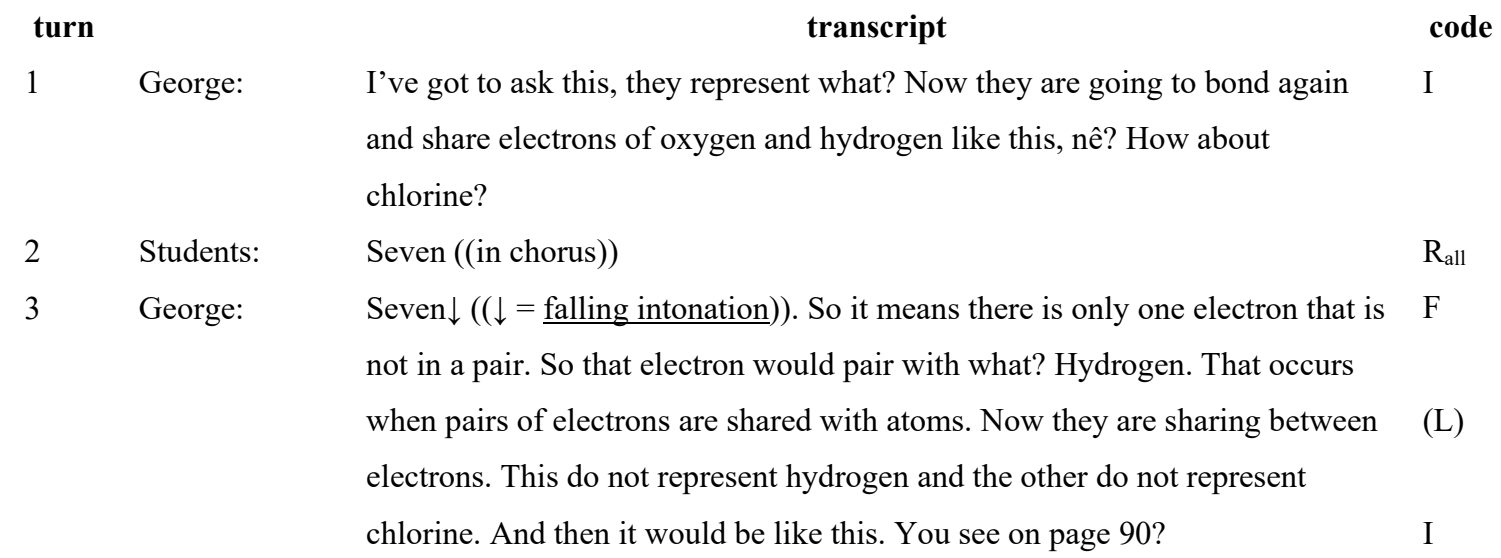


George begins the episode and the first segment by posing a question and immediately narrowing it towards teacher-desired direction. Learners respond in choir (turn 2) after which George repeats the answer with falling intonation. Although repetition could signal a neutral acknowledgement and recognition (Berland \& Hammer, 2012, p. 75), in this case, the repetition stands clearly for highly evaluative feedback which is interpreted in falling intonation and following mini-lecture directing the discussion towards a direction pre-defined by George (turn 3). In contrast, a clear wait time could be considered as tossing the turn back to learners in order to probe further ideas (Chin, 2004). George's mini-lecture is directly followed by a checking task as learners were supposed to confirm a teacher-lectured idea from the textbooks. Evaluative repetition and teacher mini-lecturing indicates the focus being set to conveying scientific principles (Note: we are not stating that this is 'bad' in every case, rather we are bringing forth indicators for a specific communicative approach). The segment ends with teacher confirmation and question and learner choir-response (turn 4).

\section{Excluding learners.}

While students are glancing at the page pointed out by George, he continues with brief presentation preluding the follow-up questions:

\section{Teacher:} So, here it is how it was done, nê. So we say plus, they are going to share and I then from here, the valence is how many? pair now and now it is stable. And then the covalence bond again, nê; it has three times of bonds. We have one we are saying is a single bond and, three bond, no-no three bond. You don't know yet, that is why you don't say three bond. It is a double bond. We don't have a single covalent bond, nê. And then we have what? is?

11 Students: $\quad$ Triple bond. ((in choir)). 
This segment continues with a questioning routine. Falling intonation feedback towards learner chorus responses (turns 6-9) reflects clearly teacher evaluation. What happens next relates to fundamental descriptions for authoritativeness. In his mini-lecture (turn 9), George begins to review the bonding of valence electrons by saying "We have one..." , which suggests that George declares the descriptions as a joint process. However, when he gets to "three bond", he takes it back: "no-no three bond", and, continues by excluding learners out of this "jointness" by announcing "You don't know that yet...”. In this way George creates the impression that he is dictating the content knowledge and also determines what learners should know. In other words, George's we refers to science insiders not including students who he rather explicitly outsides (Oliveira, 2011). Furthermore, the rest of the sentence “...that is why you don't say three bond" implies that students should not even say anything unexpected not written in the pre-defined story. In conclusion, there is only one view present: The view of science dictated by George.

\section{Singalong science.}

This segment begins with George's confirming presentation after he and students interact with rapid changes in turns resembling a well-rehearsed turn-by-turn singing performance:

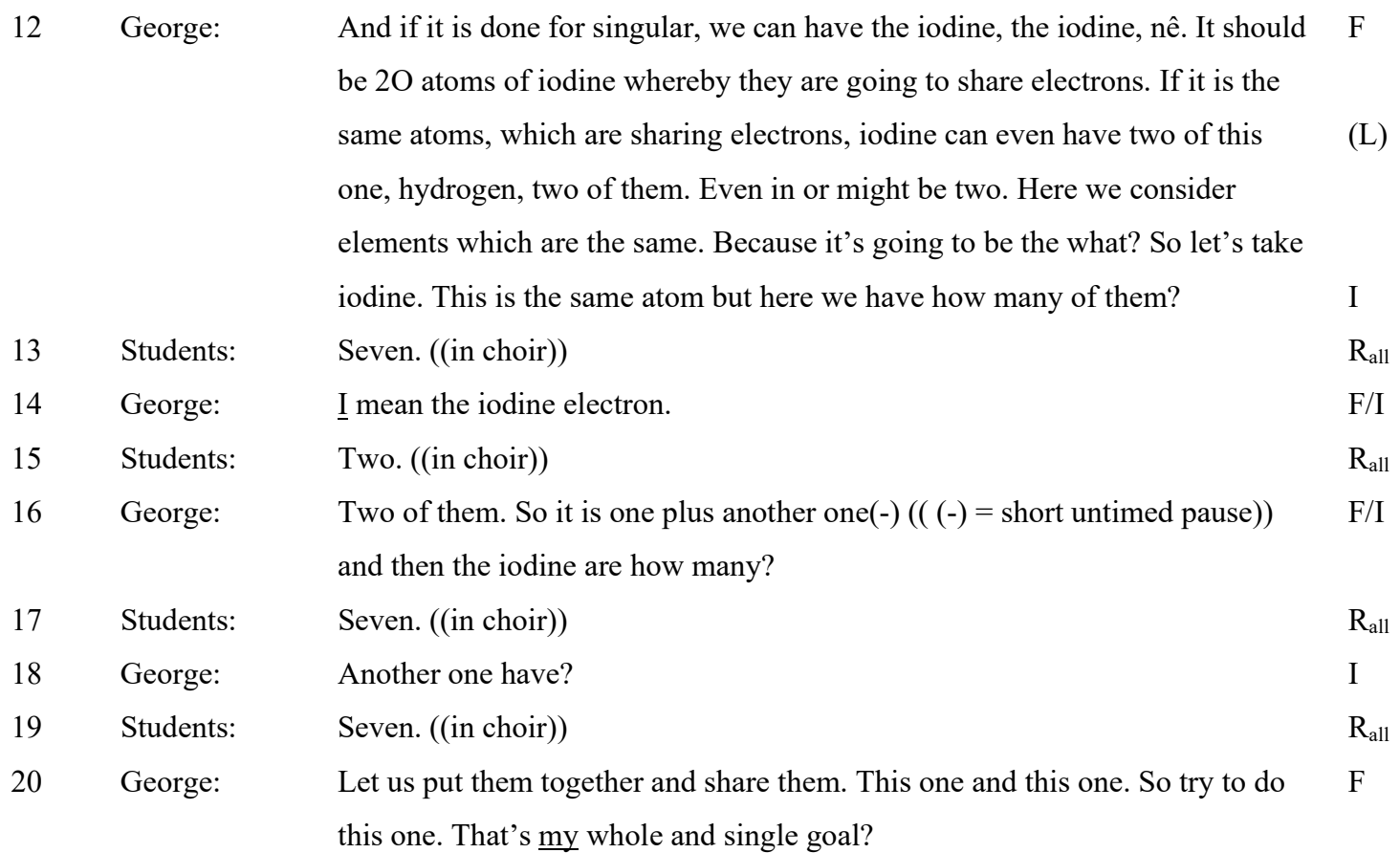


Although learners speak, they are merely playing a game, filling in a 'missing word'. This was already clearly shown in turn 10 , where George and the learners are almost singing in turn, following a song script. In this segment the clearest indicator for authoritativeness is striking out in turn 14 as George re-tunes the quire to right path and states " $I$ mean the iodine electron". Not only does this signal to learners that they were wrong, but also implies that it is the George's thinking learners should "sing" in turn. It is like following melodic staves where there is no room for improvisation. The segment ends with George giving learners a task with an ending line "That's my whole and single goal". To understand the meaning of the personal pronoun my has two options. In first option George is wording an individual learner thinking prepping him/herself for a task to come. Or, my is referring to George's mission, which at the same time is the mission of the whole class. Either way, as presented later in John's case, this does not echo with learner-centredness and dialogicity, which is obvious when reflected against the whole episode.

Overall, this kind of interaction could resemble an IRF pattern, but it is questionable whether this episode fulfils all the criteria for interactivity, since the episode is carried through in solo when it comes to delivering the science. Unarguably, since neither different ideas nor different voices are authentically being heard, this makes the episode deeply authoritative. This is explicitly implied in turn 14 when the George says "I mean the iodine electron", after which the learners correct their response (again in chorus). The end of the episode (turn 20) conforms to this interpretation, since George, again very explicitly, brings the teacher's view into focus: "That's my whole and single goal".

In addition to the example episode, another indicator of a highly evaluative, and therefore authoritative, classroom situation is the collective evaluation by the class of individual learner presentations on the blackboard. In one of these cases, when George asks of the learner presentation "is this correct?" the class responds simultaneously and loudly in chorus, "No!". Thus, the learners have clearly adopted, and are implementing, an authoritative approach in their communication.

Overall, this episode is considered as highly authoritative due mainly to the following indicators: 
- Evaluative feedback: Learners are left no space for alternate views, signaled through George's evaluative repetition and learner chorus responses.

- Excluding learners from science: George puts science in front excluding the possibility for alternative views (especially turn 9). Furthermore, George explicitly emphasizes his view and directs the discussion clearly towards it (turn 14).

- Conveying correctness: The episode constitutes a sequence of IRF(L) patterns constituting an $\mathrm{A} / \mathrm{I} \& \mathrm{NI}$ communicative approach in which the question answer routine is interrupted with mini-lectures. Through these mini-lectures George confirms the correctness of scientific content at the same time explicitly excluding learners from this process.

As the first indicator is present in theoretical overview the second and third indicator emerge mostly from data interpretations. The analysis above indicates that the transmission mode of interaction is deeply rooted in this science class - despite many learners being heard, the learners can be considered to represent a single unit simply filling slots in a pre-defined scientific agenda presented by George. This agenda is carefully carried through in the transcribed teacher mini-lectures noted earlier.

John: Sharing the ownership of science. John's lesson dealt with transverse and longitudinal waves. The episode is characterized into the following segments: Engaging with the day's topic, learner hesitation, opening up for dialogicity, collecting learners' ideas and review. Each segment will be given thorough consideration by applying discourse analysis described earlier.

Engaging with the day's topic.

In the first segment of the lesson transcript, John introduces briefly the day's topic and prompts the learners to define a wave:

turn

transcript

code

1 John: Right, but before we get to go there, we will discuss ((writes on board)). This is our topic. Wave interaction. We will talk about transverse waves, longitudinal I waves. We don't know what is a wave. That is where we need to be. Let's start. 
So my question to you, what is a wave? ((Writes on board)). What is a wave?

Can anyone help me in this subject? (-)

The episode begins by John writing the topic on the blackboard. At the same time he specifies the two forms of the waves, but questions the definition for a wave by using plural "we", which already indicates sharing the responsibility of the forthcoming discussions with the learners. In other words, the use of pronoun we could already signal to learners that pursuing through the definition of the wave will be a joint process (Oliveira, 2011, p. 1824). The first turn ends with the initiation (I), in which John poses the first actual question "What is a wave?". Immediately after this close-ended question John softens its edge by inviting learners to express their ideas by announcing “Can anyone help me in this subject?”. So, John actually invites all of the learners to the process of helping him. In this way John decreases his subject authority by asking help from the learners to his question ("So my question to you..."), in which he implies not knowing the answer. Decreasing subject authority here can be understood as teacher explicitly letting go of the omniscient role often assimilated to science teachers (Avraamidou, 2016).

\section{Learner hesitation.}

Within few seconds a few learners have raised their hands when John looks at and nods towards Mark indicating that Mark may tell his idea:

$\begin{array}{llll}2 & \text { Mark: } & \text { Yes Sir. I think it's a combination of two or more parts. } & \mathrm{R}_{1} \\ 3 & \text { John: } & \text { It is the combination of two or more parts? } \uparrow(\uparrow=\underline{\text { Rising intonation })} & \text { F/I } \\ 4 & \text { Mark: } & \text { Yes Sir. ((With quieter voice) }) & \mathrm{R}_{1}\end{array}$

Note: in $\mathrm{R}_{\mathrm{x}}$ the subscript $\mathrm{x}$ stands for number of learner; ; $\mathrm{F} / \mathrm{I}$ means that

feedback leads to learner(s) further response; initiation is embedded in teacher

feedback; or initiation is following right after the feedback and not considered as

a separate turn

Mark's responses (in particular turn 4) were barely (yet clearly) audible and signals hesitation and uncertainty marked by the quieter voice (Steinbach-Kohler \& Thorne, 2011, p. 72). Controversially to George, John repeats Mark's response with a rising intonation, which could stand for a neutral acknowledgement and recognition (Berland \& Hammer, 2012, p. 
75). The repetition feedback could also have a conversational repairing function, for example when something is not clearly heard (Hall, 2007; Macbeth, 2004). However, when reflected to forthcoming segments, the repetition with rising intonation can serve also pedagogical purpose as it indicates teacher interest towards what has been said, this way inviting learners to elaborate on their responses further (Cullen, 2002).

\section{Opening up for dialogicity.}

After learner hesitative turns, John makes a quick proxemic shift4 (Scott, Mortimer, \& Aguiar, 2006) towards learners and announces with a rising voice and intonation:

5 John

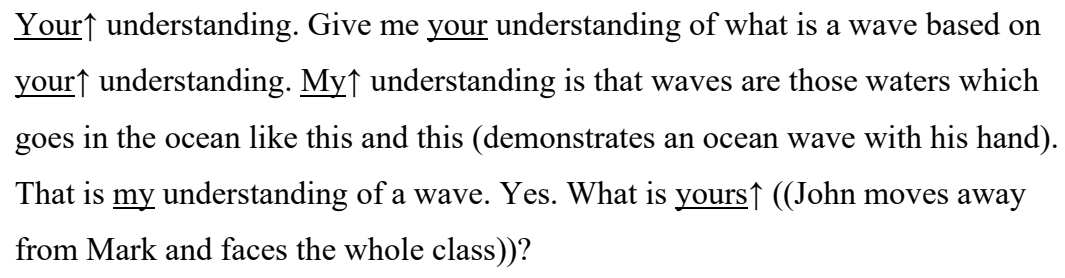

In this turn the personal pronoun "your" refers to the whole classroom in general rather than a single learner. This is evident in John's proxemic shift (away from Mark) towards the whole class and in the volume as John is inviting the whole class to share their understanding. Not only is John expressing his authentic interest, but he is also presenting a common 'everyday idea' about a wave as 'his own' ("My understanding is..."). This is the second time John decreases his subject authority and aims to get more learners involved into discussion (“... What is yours?"). Overall this turns holds in the seed for the forthcoming segment and teacher-learner exchanges.

\section{Collecting students' ideas.}

After John's supportive prompt several students raise their hands and John gives turns by pointing at individual students:

$6 \quad$ Miles: It is the interaction of(-)

$\mathrm{R}_{2}$

4 Proxemic shift stands for changes in interpersonal physical distances 


$\begin{array}{llll}7 & \text { John: } & \text { I can’t hear you Sir. } & \mathrm{F} / \mathrm{I} \\ 8 & \text { Miles: } & \text { It is the relation. } & \mathrm{R}_{2} \\ 9 & \text { John: } & \text { I don't get you. Please can you go louder? } & \mathrm{F} / \mathrm{I} \\ 10 & \text { Robert: } & \text { It is the regular. } & \mathrm{R}_{3} \\ 11 & \text { John: } & \text { It is the regular } \uparrow(-) \text { ((rising intonation and waiting for further ideas) }) & \mathrm{F} / \mathrm{I} \\ 12 & \text { Robert: } & \text { Disturbance. } & \mathrm{R}_{3} \\ 13 & \text { John: } & \text { Disturbance } \uparrow(-)(\text { rising intonation and waiting for further ideas) }) & \mathrm{F} / \mathrm{I} \\ 14 & \text { Ronnie: } & \text { In the medium. } & \mathrm{R}_{4}\end{array}$

While turns 7 and 9 could stand for conversational repairs, the preluding responses $(6 \& 8)$ are clearly audible and it is obvious that John also hears learners. The pedagogical purpose is, first of all, to encourage learners more rigorously to share their ideas in a way that the whole class would hear them. After this, learners Robert and Ronnie join the discussion with confidence (indicated by clear and louder responses). With repetition and rising intonation John welcomes their ideas neutrally (Berland \& Hammer, 2012, p. 75) and applies several seconds (3-4) wait time (turns 11 \& 13) after learner responses. Overall, John's adoption of the common everyday view seems to flip the roles as learners now use more scientific descriptions. Characteristically, dialogic discussions address everyday ideas (as presented by John), but in this case, the learners provide scientific explanations such as "regular" (turn 8) and "disturbance" (turn 12). When it comes to dialogicity, there are two dialogic indicators in this segment: repetition with rising intonation and clear wait time (Chin, 2004). Especially rising intonation is considered to support explorative forms of interaction (Skidmore \& Murakami, 2010), thus in here supporting the above interpretations by excluding evaluative aspect of repetition.

Review.

John begins the segment by reviewing learner responses this way beginning to close down the dialogic discussions:

15 John: It is the regular disturbance in a medium. Okay? In connection with pulse. It is a F combination of two pulse in a vibration. Yes(-) Yes(-) That will be correct. Anyone having a different answer?(-) ((Wait time; Class: Shuffles))... Anyone I having a different answer than those answers that have been said?(-) ((Wait time)) So when we talk about a wave, ((moves to blackboard)), a wave is a single disturbance in a medium. So it is a single disturbance. Any single 
disturbance in a medium, we call it a wave. And when we talk about a medium... ((continues lecturing))

The evaluation of learner responses signals the dialogic discussions being closed down (Lehesvuori et al., 2013) but despite this John keeps the 'dialogic space' (Scott, Ametller, Mortimer, \& Emberton, 2009; Wegerif, 2010) open by trying to elicit different views twice with complementary and notable wait time. At micro-scale this segment resembles dialogic and non-interactive approach during learners' ideas are explicitly acknowledged in teacher talk while moving towards the scientific agenda (Mortimer \& Scott, 2003; Lehesvuori et al., 2013). The proxemic shift towards blackboard finally closes the dialogic approach, hence at the same time marking the end of the episode as John begins to define the wave more authoritatively.

The episode is considered as dialogic for the following dialogic indicators presented in order of appearance:

- Sharing responsibility: John explicitly refers to learners and their understanding and not his. This is indicated through indented use of personal pronouns such as we (turn 1) and your (turn 5).

- Decreasing subject authority: John decreases his subject authority by asking learners to "help" (turn 1) and by adopting a common everyday view as his own (Note: personal pronoun my in turn 5). These together lead to learners expressing their thoughts in more scientific terms (turns 6, 8, $10 \& 12$ ). This is in contrast to George's example of excluding learners from science, since here John is like stepping away from science's side and learners take the opportunity to fill this vacuum.

- Proxemic shift: After Mark's hesitation, John makes a clear proxemic shift towards the classroom, in this way increasing attention and inviting the whole group to engage in discussions. While proxemic shifts can be used for controlling classroom and unwelcomed behavior, in this case it is assimilated to welcoming learners to take part into the discussion which is evident in teacher communication. It is advisable for the teacher to locate in a way that lures as many learners as possible to the centre of action (see Lefstein \& Snell, 2014, p. 68-69).

- Neutral repetition: In contrast to George's lesson, teacher repetition (e.g., turns 11, 13 \& 15) in John's lesson can be considered as neutral acknowledgement and recognition 
(Berland \& Hammer, 2012, p. 75). This leads to chain pattern IRFRF, which in this case confirms support for the dialogic approach, particularly due to the explicit eliciting of different views.

- Rising intonation and wait time: Neutral repetition complemented with rising intonation and wait time (turns $11 \& 13$ ) invited learners to share more ideas (turns 12 \& 14) as the fear of incorrectness had already been diminished by the previous indicators played by John.

- Explicit acknowledging of learner ideas: In the end of the episode (turn 15) John recaps learner ideas before moving toward lesson agenda and definition of the wave through lecturing. This resonates with the description of D/NI approach (Mortimer \& Scott, 2003), yet here it is at a micro-scale level.

The first two and the last indicator are interpretative-level indicators defined from the data. The other indicators are considered to be more theory-driven. Nevertheless, the presence of several indicators supports initial categorisation of dialogic approach.

\section{Discussion}

The results reveal two extremely different approaches to classroom interaction during wholeclass teaching sessions. Several indicators for constituting these approaches were detected in example episodes of George and John. Whereas George conveyed the correctness through evaluative feedback and mini-lecturing, John challenged the prevailing authoritativeness through implementation of neutral feedback, wait time and proxemic shift. Complemented with the interpretative-level indicators of sharing of responsibility and decrease of subject authority John successfully invited learners in sharing the ownership of the knowledge (Fosnot, 1996).

Whereas John opened up space for different views by initiating a dialogic episode, George provided very evaluative feedback allowing very little space for different and diverging views. The transmissive nature and over-authoritativeness was deeply rooted in this communication, merely resembling a game of 'fill in the missing word' in pre-defined sentences of scientific knowledge. And, although the episode was analysed as interactive in the turn-by-turn analysis, we are left with the question of whether this 'game' even fulfils the fundamental criteria for an authentic interactive and reciprocal interaction (Alexander, 2006; 
Mortimer \& Scott, 2003). Despite John's lesson being overall also authoritative, he was able to reach dialogicity in the presented example episode. The 'flipping of the roles' in John's example illustrates a rather infrequent phenomenon - that of individual learners' ideas being authentically heard as they 'take over' the scientific agenda.

In conclusion to above, we argue that when John decreased his subject authority and 'benched' himself (“Can anyone help me in this subject?”), learners took over and substituted him as a 'playing squad of science' (E.g., "Regular", "Disturbance”). Vice versa, George 'owned the field' and excluded learners by announcing: "You don't know that yet, that is why you don't say three-bond". We acknowledge that different topics can be addressed in different ways, yet the George's example demonstrates that the learners' role was merely to support George pursuing through scientific story with choir-singing. In many descriptions and examples of dialogic interactions (Mortimer \& Scott, 2003; Lehesvuori et al., 2013), dialogic episodes are characterised by learners sharing their everyday ideas. However, although we cannot fully confirm how learners arrived at the more scientific ideas expressed, we have brought up that John's 'flipping of the roles' finally engaged learners to share their ideas after hesitation.

The distinction between authoritative and dialogic approaches is not always straightforward and dichotomous. Instead, according to Scott, et al. (2006) there is a tension between these two and one approach seeds the other. However, as an exception to many previous studies, this study illustrates two episodes from the opposite ends of the dialogic-authoritative continuum. This is especially evident in personal pronouns such as: "I mean...[George]" vs. "Your understanding... [John]". Similarly, when considering more holistic approaches to teaching (with fewer words), 'I' in here indicates teacher-centredness, and 'your' indicates learner-centredness particularly in the context of the analyzed examples. Although there is some research addressing the use of pronouns and their effectiveness in teacher education context (Oliveira, 2009, 2011), we have not found (e.g., Lehesvuori, Viiri, \& RaskuPuttonen, 2011; Lehesvuori et al., 2013) these being connected to the descriptions of communicative approaches via this explicit examples of classroom interactions in science classroom realities.

We maintain that the kind of explicitness fostered in the dialogic approach in this study is the only way to challenge the prevailing authoritativeness still detected in most PST lessons in 
South Africa, as well as in in-service teacher lessons in Finland (Lehesvuori et al., 2013). It would have been easy for John just to tell what a wave is after learner hesitation, but instead he was determined to break through the prevailing authoritativeness. A simple prompt "Your understanding" may seem very modest by itself, but in this context it was exceptional. Although only for one episode and barely a minute, John still succeeded to reach dialogicity in a way that is infrequently found in science classrooms. The actions of John indicate some awareness of dialogic principles, which could have led him playing the "dialogic cards" despite the seemingly bad odds and risk of failure. As described by Alexander (2006), in order to be sufficiently integrated into teaching, dialogicity should be present in three different levels: principles, techniques and indicators5. As the overall interactions was still overly authoritative in overall video data it can be hypothesised that work is still needed in order to address and have change on the principles. As noted, it is expected John's principles of dialogicity might have influenced John's behavior, yet only one, and quite brief, dialogic episode indicates lack in repertoire in techniques that could be used to bounce between different approaches more frequently during the lessons.

Having said this, before inquiry guidelines can be fully integrated in teaching and learning, dialogic interaction must be realized in classroom realities and teacher education in different levels. Principles are the key to change in awareness, which could lead to manifestation of indicators such as played by John. However, in order to deliver the school science in meaningful way, repertoires of techniques should be practiced already in teacher education. For example, ways on how to proceed from learner everyday views to science view via scientific inquiry could be explicitly planned and executed by using pre-existing structures for dialogic inquiry-based teaching and learning (Lehesvuori et al., 2011). Classroom interactions in science should contain both dialogic and authoritative approaches to facilitate more meaningful learning in science (Scott \& Ametller, 2007), but the way these approaches could be linked to inquiry should be explicitly discussed.

In view of the dominant authoritative approaches that have been revealed through other studies (Mercer, Dawes, \& Staarman, 2009; Author et al., 2013), it is imperative that strategies and cases be explored in order to challenge it. This is possible through teacher

${ }_{5}$ We have assimilated the idea of the different levels to macro-, meso- and micro-levels of analysis through which classroom interactions can be temporally addressed (Author et al., 2013) 
education, where dialogic approaches are explicitly practised (Lehesvuori, Viiri, \& RaskuPuttonen, 2011). In previous studies in Finland, different forms of interaction were practised during a one-year teacher education programme, in which PSTs were supported in intentionally planning, implementing and reflecting on different communicative approaches. Although results revealed success in adopting a more dialogic approach in teaching, and in influencing the views of PSTs, the example of John in this study captures the essence of possible reform: the explicitness of dialogicity should be present. This kind of explicitness can finally lead to learners understanding and acquiring the communication skills needed for dialogic interaction, such as dialogic argumentation and exploratory talk (Mercer, 2009). More dialogic examples are needed, which can only be attained by greater use of explicit dialogic approaches in teacher education, and the intentional practice of varying communicative approaches. Continuingly, as addressed in the introduction, although teacher talk cannot be planned turn-by-turn, and sentence-by-sentence, it is at the micro-level that a teacher can in an accessible way reflect the difference between authoritative and dialogic approaches through related indicators. Different approaches to communication can be then considered at the episode-level (meso-level) when connecting them to specific teaching purposes and activities. The concept of communicative approach can be, thus, invoked as a theory-based planning tool (Lehesvuori, Viiri, \& Rasku-Puttonen, 2011; Mortimer \& Scott, 2003).

\section{Implications and Limitations}

Since classroom interaction constitutes of many, and even complex, interlacing features, it is recommended that tools are developed and applied to address one specific aspect in greater depth, rather than trying to model the overall teaching process. However, focusing only on features such as questioning or teacher feedback does not necessarily provide sufficient holistic information about the true nature of communication, and could even give a misleading overview of teacher-led interactions. Having said this, interpretations of the dialogic communicative approach, for instance, holds promise for authentic learner-centred indicators brought up in this study. However, in order to capture the dialogic essence of these forms of interaction, multi-layered analysis is required within and between different temporal units of analysis in order to arrive at a more holistic view of the interactions taking place in science classrooms. We acknowledge the lack of temporality in this study as a limitation. 
However, as the examples were exceptional in terms of explicitness, we think the interpretations, backing up to conversation analysis in micro-scale, are trustworthy.

Micro-scale approach to analysis is essential when delving into the development of characterization of communicative approaches, yet more temporal analytical approaches are required when seeking unique teachers applying extensively and varyingly different approaches of communication. Teaching science should not be merely singing the scientific agenda in choir, rather there should be room for creativity and improvisation to make learning more meaningful to learners (Scott \& Ametller, 2007). In musical terms, there should be a little more 'jazz' present, than merely 'melodic mainstream'. Despite, as important harmony is, and harmonic polyphony is safe and comfortable, it is still the breaking nuances that could make the difference between forgettable and memorable. Thus, teachers should every now and then leave their comfort zone in order to challenge both themselves and learners in breaking the prevailing forms of interactions.

Having said this, understanding of dialogic indicators is elemental both in classrooms and teacher education if the aim is to steer transmission modes of teaching in a more varying, dialogic and learner-centred direction. The social aspects should be integrated into inquirybased teaching, and this is possible only by studying teaching examples of whole-class discussions. This study briefly addressed how learners had adopted the evaluative form of talking within a clearly authoritative classroom climate. Controversially, it can be hypothesised that learners may also acquire dialogic aspects in their communication. However, this can only be realised if these aspects are frequently, purposefully and, most importantly, explicitly, brought forth in teacher-orchestrated discussions. To enhance this, the social, and especially dialogic, aspect should be clearly present in teacher education (Lehesvuori, Viiri \& Rasku-Puttonen, 2011). Whether this integration of inquiry and social aspect would take place, the effect on classroom interactions should also be explored in continuation studies in South Africa and other countries renewing their curricula towards learner-centred direction. (E.g., Finland, Finnish National Board of Education, 2013). It remains to be seen whether there will be a little more 'jazz' in addition to comfortable 'mainstream melody'.

Finally, apart from acquiring scientific knowledge, lifelong learners should be able to argue, criticize, solve problems and to communicate (Bybee, 2010), which are skills closely related 
to inquiry guidelines and scientific argumentation. After all, these skills are the origins of science and should continuously be emphasised in teacher talk in science classrooms. These skills are almost inevitably developed in dialogic interaction. And, as indicated in this study, dialogic interaction is a shortcut to learner-centredness.

\section{Acknowledgements}

Authors gratefully acknowledge the insightful comments received from external scholars during the process.

\section{References}

Alexander, R. (2006). Towards dialogic teaching (3rd ed.). York: Dialogos.

Anderson, R. D. (2007). Inquiry as an Organizing Theme for Science Curricula. In S. K. Abell \& N. G. Lederman (Eds.), Handbook of research on science education (pp. 807-830). London: Routledge.

Andrews, T. M., Leonard, M. J., Colgrove, C. A., \& Kalinowski, S. T. (2011). Active learning not associated with student learning in a random sample of college biology courses. CBE-Life Sciences Education, 10(4), 394-405.

Avraamidou, L. (2016). Studying science teacher identity: Theoretical, methodological and empirical explorations. Rotterdam: Sense Publishers.

Bakhtin, M. (1986). Speech genres and other late essays. Austin: University of Texas Press.

Berland, K. B., \& Hammer, D. (2012). Framing for scientific argumentation. Journal of Research in Science Teaching, 49(1), 68-94.

Braun, V., \& Clarke, V. (2006). Using thematic analysis in psychology. Qualitative Research in Psychology, 3(2), 77-101.

Bybee, R. (2000). Teaching science as inquiry. In J. Minstrell, and Emily H. van Zee (Ed.), Inquiring into Inquiry Learning and Teaching in Science. Washington: Washington, DC: AAAS

Bybee, R. (2010). The teaching of science: 21st century perspectives. Arlington, VA: NSTA Press

Chin, C. (2004). Questioning students in ways that encourage thinking. Teaching Science, 40(4), 16-21. 
Chin, C. (2007). Teacher questioning in science classrooms: Approaches that stimulate productive thinking. Journal of Research in Science Teaching, 44(6), 815-843.

Cohen, L., Manion, L., \& Morrison, K. (2007). Research Methods in Education. (6th ed.) London: Routledge Falmer.

Cullen, R. (2002). Supportive teacher talk: The importance of the F-move. ELT Journal, 56(2), 117-126.

Edwards, D., \& Mercer, N. (1987). Common knowledge. London: Methuen/Routledge.

Finnish National Board of Education (FNBE). (2013). OPS 2016 - Renewal of the core curriculum for pre-primary and basic education. Retrieved from

http://www.oph.fi/english/current_issues/101/0/ops2016_renewal_of_the_core_curriculum_f or_pre-primary_and_basic_education

Furtak, E. M., \& Shavelson, R. J. (2009). Guidance, conceptual understanding, and student learning: An investigation of inquiry-based teaching in the US. In T. Janik \& T. Seidel (Eds.) The Power of Video Studies in Investigating Teaching and Learning in the Classroom. Munich: Waxmann, 181-206.

Hall, J.K. (2007). Redressing the roles of correction and repair in research on second and foreign language learning. The Modern Language Journal, 91, 511-526.

Kiemer, K., Gröshner, A., Pehmer, A-K., \& Seidel, T. (2015). Effects of a classroom discourse intervention on teachers' practice and students' motivation to learn mathematics and science. Learning and Instruction, 35, 94-103.

Lefstein, A., \& Snell, J. (2014) Better than Best Practice: Developing Teaching and Learning through Dialogue. London: Routledge.

Lehesvuori, S., Ratinen, I., Kulhomäki, O., Lappi, J., \& Viiri, J. (2011). Enriching primary student teachers' conceptions about science teaching: Towards dialogic inquiry-based teaching. Nordic Studies in Science Education, 7(2), 140-159.

Lehesvuori, S., Viiri, J., \& Rasku-Puttonen, H. (2011). Introducing Dialogic Teaching to Science Student Teachers. Journal of Science Teacher Education, 22(8), 705-727.

Lehesvuori, S., Viiri, J., Rasku-Puttonen, H., Moate, J., \& Helaakoski, J. (2013). Visualizing communication structures in science classrooms: Tracing cumulativity in teacher-led whole class discussions. Journal of research in science teaching, 50(8), 912-939.

Lemke, J. L. (1990). Talking science: Language, learning and values. Norwood: Ablex Publishing Company.

Littleton, K., \& Howe, C. (Eds.). (2009). Educational dialogues: Understanding and promoting productive interaction. London: Routledge.

Lyons, T. (2006). Different countries, same science classes: Students' experiences 
of school science in their own words. International Journal of Science Education, 28(6), 591613.

Macbeth, D. (2004). The relevance of repair for classroom correction. Language in Society $30,703-736$.

McMahon., K. (2012). Case Studies of Interactive Whole-Class Teaching in Primary Science: Communicative approach and pedagogic purposes. International Journal of Science Education, 34(11), 1687-1708.

Mehan, H. (1979). Learning lessons: Social organization in the classroom. Cambridge, MA: Harvard University Press.

Mercer, N. (2004). Sociocultural discourse analysis: analysing classroom talk as a social mode of thinking. Journal of Applied Linguistics, 1(2), 137-168.

Mercer, N. (2009). Developing argumentation: lessons learned in the primary school. In M. N. Muller \& A-N. Perret-Clermont (Eds.), Argumentation and education: theoretical foundations and practices. Berlin: Springer.

Mercer, N., Dawes, L., \& Staarman, J.K. (2009). Dialogic teaching in the primary science classroom, Language and Education, 23(4), 353-369.

Mercer, N., Dawes, L., Wegerif, R., \& Sams, C. (2004). Reasoning as a scientist: Ways of helping children to use language to learn science. British Educational Research Journal, 30(3), 367-385.

Miles, M. B., \& Huberman, A. M. (1994). Qualitative Data Analysis (2nd edition). Thousand Oaks, CA: Sage Publications.

Mortimer, E. F., \& Scott, P. (2003). Meaning making in science classrooms. Milton Keynes: Open University Press.

Myhill, D. (2006). Talk, talk, talk: Teaching and learning in whole class discourse. Research Papers in Education, 21(1), 19-41.

Nassaji, H., \& Wells, G. (2000). What's the use of "triadic dialogue"?: An investigation of teacher-student interaction. Applied Linguistics, 21(3), 376-406.

Nystrand, M., Gamoran, A., Kachur, R. \& Prendergast, C. 1997. Opening dialogue: Understanding the dynamics of language and learning in the English classroom. New York: Teachers College Press.

Oliveira, A. W. (2009). Developing elementary teachers' understandings of hedges and personal pronouns in inquiry-based science classroom discourse. Journal of Research in Science Education, 8(2), 247-269.

Oliveira, A. W. (2010). Improving teacher questioning in science inquiry discussions through professional development. Journal of Research in Science Teaching, 47(4), 422-453. 
Oliveira, A. W. (2011). Science Communication in Teacher Personal Pronouns, International Journal of Science Education, 33(13), 1805-1833.

Osborne, J. (2014). Scientific practices and inquiry in the science classroom. In N. K. Lederman \& S.K.Abell (Eds.), Handbook of research on science education, Volume II. New York: Routledge.

Patton, M. Q. (1990). Qualitative evaluation and research methods. Newbury Park, CA: Sage.

Peters, E. E. (2010). Shifting to a student-centered science classroom: An exploration of teacher and student changes in perceptions and practices. Journal of Science Teacher Education, 21(3), 329-349.

Ramnarain, U. \& Kibirige, I. (2010). Learning through investigations. In U. Ramnarain (Ed.). Teaching scientific investigations (pp. 1-23). South Africa: Macmillan.

Rojas-Drummond, S., Mercer, N., \& Dabrowski, E. (2001). Collaboration, scaffolding and the promotion of problem solving strategies in Mexican pre-schoolers. European Journal of Psychology of Education, XVI(2), 179-96.

Saari, H., \& Sormunen, K. (2007). Implementation of teaching methods in school science. In E. Pehkonen, M. Ahtee \& J. Lavonen (Eds.), How Finns learn mathematics and science (pp. 215-228). Rotterdam: Sense Publishers.

Scott, P., \& Ametller, J. (2007). Teaching science in a meaningful way: Striking a balance between 'opening up' and 'closing down' classroom talk. School Science Review, 88(324), $77-83$.

Scott, P., Ametller, J., Mortimer, E., \& Emberton, J. (2010). Teaching and learning disciplinary knowledge: Developing the dialogic space for an answer when there isn't even a question. In K. Littleton \& C. Howe (Eds.), Educational dialogues: Understanding and promoting productive interaction (pp.322-337). London: Routledge.

Scott, P. H., Mortimer, E. F., \& Aguiar, O. G. (2006). The tension between authoritative and dialogic discourse: A fundamental characteristic of meaning making interactions in high school science lessons. Science Education, 90(4), 605-631.

Simons, H. (2015). Interpret in context: Generalizing from the single case in evaluation. Evaluation, 21, 173-188.

Sinclair, J., \& Coulthard R. M. (1975). Towards an analysis of discourse. Oxford: Oxford University Press.

Skidmore, D., \& Murakami, K. (2010). How prosody marks shifts in footing in classroom discourse. International Journal of Educational Research, 49(2-3). 69-77.

Steinbach-Koehler, F., \& Thorne, S. L. (2011). The Social Life of Self-Directed Talk: A Sequential Phenomenon? In J. Hall, J. Hellermann, S. Pekarek Doehler, \& D. Olsher (eds.), 
L2 Interactional Competence and Development (pp. 66-92). Bristol, UK: Multilingual Matters.

Webb, N. (2009). The teacher's role in promoting collaborative dialogue in the classroom. British Journal of Educational Psychology, 79(1), 1-28.

Wegerif, R. B. (2010). Dialogue and teaching thinking with technology: Opening, expanding and deepening the 'inter-face'. In K .Littleton \& C. Howe (Eds.), Educational dialogues: Understanding and promoting productive interaction (pp.338-357). London: Routledge.

Wells, G., \& Arauz, R. (2006). Dialogue in the classroom. Journal of the Learning Sciences, 15(3), 379-428. 